\title{
Student Discipline Management: An Examination of the State Secondary School Principal's Leadership in Mauritius
}

\author{
Louis Jinot Belle (Corresponding author) \\ Lecturer, Department of Education \\ Open University of Mauritius, Reduit, Mauritius \\ Tel: $23057124044 \quad$ E-mail: 1.belle@open.ac.mu
}

Received: December 9, 2017 Accepted: December 28, 2017 Published: January 17, 2018

doi:10.5296/ire.v6i2.12271ＵRL: http://dx.doi.org/10.5296/ire.v6i2.12271

\begin{abstract}
The purpose of this study was to determine the leadership approaches that state secondary school principals adopt in Mauritius in order to manage student discipline. Semi-structured interviews and non-participant observation were done in this multisite case study. Purposive convenient sampling was used to gather information from 84 participants. It was found that principals use visionary leadership, distributed leadership, learner leadership, inclusive leadership and ethical leadership. This is the result of the political and legal framework, the unwillingness of the educators to assume their professional commitment to discipline students, the complicated protocol to be observed by principals to address indiscipline, and the feeling of disempowerment of the principal to manage student behaviour due to the centralisation of the education system. The study recommends for a mix of leadership approaches to ensure effective student discipline.
\end{abstract}

Keywords: leadership approaches, indiscipline, manage, student behaviour

\section{Introduction}

Education is defined as the processes which transmit the relevant knowledge, attitudes, skills, values, aptitudes and practices of culture in order to facilitate the cognitive, emotional and social skills of the students, and hence their moral thinking, feelings, actions and reactions (Pushpa, 2014; Das, 2017). Sisman (2011) adds that students also learn arts, music and character education so that they may positively deal with behavioural changes. Adolescent students in secondary schools may face numerous personal, interpersonal, social, psychological and behavioural problems since they are at a stage of their life when they are 
building their self-concept in terms of their self-awareness, self-confidence, self-satisfaction, self-worth and self-value (Rahman, Shahrin \& Kamaruzaman, 2017). They are in the process of disorientation and discovery (Naganandini, 2017). So, it is the school as a planned, well-organised and settled organisation that must have the function to allow them socialise, recognise and realise themselves as human beings (Dos \& Savas, 2015). The school should establish a safe, non-disruptive teaching and learning environment (Lane, Cook and Tankersley, 2013) to ensure their physical, emotional and intellectuall safety (Osher \& Kendziora, 2010). According to Themane and Osher (2014), such a school is an effective one as it also ensures that students are connected and supported by their educators and the principal, they are engaged in learning and the students, the educators and the principal are practicing good social and emotional skills. The school should therefore be student-centred (Pushpa, 2014; Dos \& Savas, 2015).

However, though the Mauritian Ministry of Education and Human Resources, Tertiary Education and Scientific Research (2015) maintains that "providing a safe, secure and supportive environment where there is responsible social behaviour is a key priority of the school, and discipline is a necessity for the proper functioning of the school", yet secondary schools in Mauritius are not functioning effectively. They are no longer safe havens for adolescents (Beebeejaun-Muslum, 2014). Discipline has become one of the major public health problems in secondary schools (Edinyang, 2017). It has become the greatest concern for all stakeholders namely the school principal, the parents, the policy-makers at the Ministry of Education, educators and the school superintendents who are overwhelmed by the numerous forms of disruptive behaviour by students on a daily basis. According to the Global School based Student Health surveys carried out in Mauritius in 2007 and 2011, there are on average $34 \%$ of secondary school students who manifest aggressive behaviour at least once every year (Jeannot, 2015). Studies carried out by Ramahrai, Curpen and Mariaye (2006), Beebeejaun-Muslum (2014) and Belle (2017) found that the teaching and learning environment in state secondary schools in Mauritius is drastically deteriorating due to the absence of student discipline and principal's ineffective leadership.

\section{Purpose of the Study}

In this context of the learner discipline situation in Mauritian state secondary schools, it is of utmost importance to study the leadership of the principals. This is likely to give the stakeholders insights into the effectiveness of the principal in dealing with this school problem. The purpose of this study is also to gauge the degree to which principals are successful in leading student behaviour among adolescents. It will also help policy-makers to have insights into the factors that may prevent the school heads from exercising their leadership function in addressing the student behaviour problem.

\section{Theoretical Framework}

\subsection{Learner Discipline}

Learner discipline is a multifaceted and complex school problem that is difficult to define since it may be considered from various perspectives. This is because human behaviour is a 
complex phenomenon (Moges, 2017). We may start with the custodial view of discipline as the degree of order and structure in a school (Mukuria, 2002) that is required to maintain socially desirable behaviour among students (Ugboko \& Adediwura, 2012). So, this implies discipline as conforming to set rules and obedience to them as well as punishment and control (Darch \& Kameenui, 2003). However, this reactive approach to discipline is likely to affect negatively the student. For instance, in a study in New York City public schools over 2015 and 2016, Eden (2017) found that the use of reactive and punitive strategies such as suspension and detention can have a domino effect on students by lowering their academic progress, by increasing misbehavior and decreasing the overall school attendance. Furthermore, Ncontsa and Shumba (2013) found that the main effects of student disruptive behaviour in South Africa are depressed students, loss of learning and teaching time, high student absenteeism and dropout rate, and educators are demoralised as they feel helpless in successfully addressing misbehaviour. However, in another study in India, with the introduction of the "No detention policy", under the Right to Education Act, it was found that when reactive measures are no more implemented, students do not care much for their studies and they show less respect for educators (Chakraborty, Tarafdar \& Ahmad, 2017). This implies that they become less discipline. In addition, the school-to-pipeline policy to discipline students and the zero-tolerance policy have witnessed much debate in US due to the negative impacts on the misbehaved student who is considered as the problem. Nevertheless, there is a lack of systematic evidence on the prevalence and effectiveness of these policies (Curran, 2017). So, the conception of discipline from this traditional perspective has much been debated.

On account of the negative effects of using reactive and punitive strategies, discipline models such as the responsive classroom model, the Jones' tools for teaching model, Nelson, Lott and Glenn's positive discipline model, the Johnson and Johnson's model, the Canter's positive behaviour management model and the school-wide positive behavioural support (SWPBS) model propound that the disruptive student should be the solution by teaching self-discipline to him/her and that any disciplinary strategy should be student-focused. This has given rise to the humanistic perspective of learner discipline. Recent literature maintains that discipline should be viewed as a process which allows the student to be personally responsible for his/her behaviour and to be able to judge between right and wrong (Fields \& Fields, 2006). It goes beyond punishment: the school should teach self-discipline (Serame, Oosthuizen, Wolhuter \& Zulu, 2013). Jones (2001) defines self-discipline as the "internalisation of discipline", which ensures the student to develop autonomy and responsible citizenship (Bear, 2010). Mahatmaharti, Triyono and Hanurawan (2017) add that it should be viewed as a constructive and positive force measured through three dimensions: self-ability to delay satisfaction, self-regulating ability and self-control. Students are thus taught to be responsible for their own behaviour (Pushpa, 2014).

This conceptualisation of discipline gives rise to the proactive or preventive approaches to discipline. Preventive approaches to discipline are choice-making, self-management, use of praise, increasing student opportunity to respond, compliance training, check-in/check-out, positive peer reporting, pre-correction, active supervision, rules and behaviour expectations, 
providing feedback, compliance behaviour game and replacement behaviour training (Hulac, Terell, Vining \& Verstein, 2011; Lane, Cook \& Tankersley, 2013; Lane, Menzies, Bruhn \& Crnobori, 2011: 101-148). For positive behaviour management to be effective, it should be contextualised, that is school-based. Alone, the principal cannot manage the discipline problem. He/she needs to rethink about his/her leadership so that he/she is effective in creating the most conducive and safe learning environment. Indeed, Gambo and Muktar (2017) ascertain that discipline is one of the main attributes of an effective school, and a lack of it is the result of a lack of effective leadership from the principal (Beebeejaun-Muslum, 2014; Ramjanally, 2015). The school principal has, therefore, a significant role to play in maintaining positive discipline among secondary school students.

\subsection{The Functions of the Principal}

The principal is the top most member in the school administration hierarchy who must run the school in such a way that satisfies the educators, students, parents and even the society; that is, he/she must ensure the administrative effectiveness of the school as an organization (Pandey, 2017). This implies that the school head functions as a manager. Belle (2015) defines management as the activities that bring order and consistency to the school organisation by drawing up formal plans, designing rigid organisational structures and monitoring results against the plans. However, Belle (2007) found that he/she should be a manager as well as a leader as he/she functions in relation to people. Indeed, education should be both people-oriented and task-oriented if schools are to be effective. Mendels (2012) concurs that $21^{\text {st }}$ century principals must focus not only on building management or other administrative matters but also on instruction.

Within the Mauritian education system, the functions of the state secondary school principal are categorised into three dimensions: administrative, pedagogical and socio-cultural. The administrative functions are setting up committees; attending and chairing meetings; attending files and mail; organising work; writing reports; supervising staff and administration of personal matters; administration of student matters, and enforcement of rules and regulations; management of material, human, financial, and infrastructural resources. The pedagogical dimension consists of controlling the implementation of curriculum; planning, organising and monitoring of instruction and other educational activities; managing learning resources; and ensuring the quality of education. The socio-cultural dimension consists of promoting health standards; promoting social and cultural values; enhancing school environment, and developing school partnership with the community (Ministry of Education, Culture and Human Resources, 2009). So, principalship in Mauritius is mainly based on administrative leadership (Farah, 2013; Baltaci \& Balci, 2017) and instructional leadership (Manaseh, 2016).

It is obvious from the foregoing discussion that the principal has a fundamental significant role to play in school improvement, the academic success and behaviour of the students (Meador, 2017). He/she is "a conductor or the principal performer in an orchestra" (McDargh, 2014). Therefore, he/she is the main source of influence in the school context when it comes to bring a change in student behaviour on the school premises. Lieber and 
Tissiere (2015) posit that the secondary school principal plays a leading rolle in the school.

\subsection{The Principal as the Leader of Learner Discipline Management}

For the school leader, one of his/her challenges is the management of student behaviour (Ministry of Education, Culture and Human Resources, 2009; Olowoselu \& Aishatu, 2015). Though he/she assumes many functions in areas as discussed in the previous section, yet he/she must spend some of his/her time addressing school discipline and student behaviour (Meador, 2017). In fact, Newcomer and Lewis (2016) point out that principals spend much of their time to address student indiscipline. The principal must use the ambidextrous leadership where he/she strikes a balance between administrative tasks and maintaining student discipline through his principalship (Smyth, 2015). Indeed, the Student Behaviour Policy document stipulates that the state secondary school principals must do the following to be an effective principal in dealing with student indiscipline:

"stimulate a school-wide approach in preventing indiscipline; lead by example by being regular and punctual; work in partnership with parents to develop and support the social and emotional skills of students; promote a positive school culture; act promptly against all forms of student indiscipline; develop a sense of belonging to the school among the students; provide support to educators in their attempt to sustain high behaviour standards; arrange in-house sharing experiences and good practices; and organise and facilitate training of staff to successfully manage challenging behaviour." (Ministry of Education and Human Resources, Tertiary Education and Scientific Research, 2015).

Therefore, much of the principal's job is to lead student behaviour. Leading student behaviour can only be effective when the principal adopts various approaches to leadership.

\subsubsection{Visionary Leadership}

Visionary leadership focuses on creating and articulating the vision of the principal. It provides meaning, purpose and values to the realisation of the core mission of the school (Bawany, 2015; Nwachukwu, Chladkova, Zufan \& Platunji, 2017). Principals perform the following three activities in order to maintain positive discipline or address student behaviour problem: (a) crafting their vision about their goals for discipline management, (b) align the educators, the superintendent, the parents and the students with the vision, and (c) inspire these people by supporting them and recognising their efforts to adopt socially acceptable behaviour, through praise and feedback (Teckchandani \& Schultz, 2014; Wyatt, 2015). Dammika (2016) mentions Kirkpatrick (2004) to point out that principals empower these people to work towards the vision; consciously build a positive image of themselves to inspire these followers; take risks in an attempt to make positive change in the behaviour of students; emotionally support, coach and mentor them about positive behaviour; intellectually stimulate them to challenge the existing unhealthy culture of learning and teaching; and motivate the stakeholders by training and acculturating them in a safe and saner school environment. The students will then feel more connected to the school and be more prepared to engage in positive behaviour (Veilmetter \& Sell, 2014). 


\subsubsection{Values-based Leadership}

School principals lead the student behaviour by setting examples of positive behaviour in their interactions with them daily. They model self-discipline and respect for the students (Temitayo, Nayaya \& Lukman, 2013). Here, values imply every attitudes and behaviour that is good and desirable (Shatalebi \& Yarmohammadian, 2011). Larmer (2001) refers to the moral value convenant of the school as an organisation where the common values direct the behaviour and actions of students towards the school's mission and vision. In the same vein, the values connectivity paradigm proposed by Shatalebi and Yarmohammadian (2011) suggests that the principal should use the adaptive leadership where personal values, the school culture and values and the power and emotional commitment of each individual converge all towards the principal's vision so that positive relationships and attitudes emerge. This is likely to promote positive behaviour among the students.

\subsubsection{Instructional Leadership}

The principal has the responsibility to ensure that instruction is done effectively in classes. Though Protheroe (2011) opines that effective leadership is more oriented towards instruction than student discipline, yet effective leadership has a significant impact on the students' academic progress and behaviour (Ugboko \& Adediwura, 2012). One of the dimensions of instructional leadership is promoting positive school learning climate in terms of the norms and behaviour of the students that may affect the instructional process (Malud, Piaw, Alias \& Mei Wei, 2017).

According to Hallinger, Walker, Nguyen, Thruong and Nguyen (2012), the instructional practices of the principal that may instil positive student behaviour are managing the instructional programme, promoting harmonious relationships among educators and students, promoting the school learning climate, and managing external relationships (with parents and the community). Besides, the principal must clearly establish his/her expectations about student discipline, organise judiciously the time of the students, make sure there is availability of learning and teaching materials, design activities that are relevant to their needs, give immediate feedback to them, teach and reinforce socio-emotional skills as well as emotional intelligence skills (Olley, Cohn \& Cowan, 2010).

\subsubsection{Distributed Leadership}

The principal must empower the educators in behaviour management and in promoting positive behaviour in the school among all students. He/she should eliminate the asymmetrical relationship that exists between them so that trust prevaills (O'Brien, 2015). Carr and Chearra (2004) add that the school head must promote collegiality or collective efficacy around values and high order purposes for positive discipline so that each educator collaborates towards a positive school climate, devoid of students' lack of discipline. By so doing, educators are likely to take more ownership of the disciplinary management strategies.

Educators are given the freedom and power to set up disciplinary committees, consultative meetings about student discipline and put into actions effective disciplinary actions that they design themselves under the leadership of the principal. They must have the feeling that they 
have a "voice" and a "choice" over discipline management (Witz, 2014). This is the inclusive and consultative approach to leadership that the principal must adopt to be effective in addressing behaviour problems (Naicker \& Mestry, 2013).

\subsubsection{Learner Leadership}

For school leadership to be effective, it should be student-focused. Students represent the main agents in the school as an organisation. Since the study is focusing on disruptive behaviour among secondary school students, it is obvious that the leadership of the principal in dealing with this problem, which concerns the students fundamentally, must take into consideration the students, more particularly. Indeed, Ugboko and Adediwura (2012) maintain that the principal needs the participation of students in his/her attempt to address behaviour problem. Students should be part of the solution to this problem (Bennett, 2015).

Walcott, Grimm and Konstan (20120 and Asiyai (2012) assert that the principal must engage all students in student discipline management strategies to instill a healthy school culture and climate. For instance, secondary school students must participate in matters such as rules, sanctions, rewards, curriculum design, teaching and learning methods, management and development planning. This will encourage them to respond positively to the school disciplinary policies. The principal may also adopt the perfectship model which gives students the opportunity to participate in the decision-making process about school matters and activities. This student-led leadership given to the students has a positive impact on the peers, helping to create a violence-free school (Pedersen, Yager \& Yager, 2011).

It is obvious that the principal should use a spectrum of leadership approaches in an attempt to promote positive discipline among secondary school students. His/her leadership should not be the "hero-paradigm" leadership where he/she commands and controls everything and everyone in the school (Lazaridou, 2009); it is not about "wielding of power to foster authority but rather the welding" of educators as well as the students together in constructing a school with positive student discipline (Bell, 2015).

\section{Methodology}

This study drew on the qualitative inquiry method to collect information about the leadership of the principals in dealing with disruptive student behaviour. It is a multisite case study. The researcher aimed at understanding the daily-life experiences of the participants about the leadership of the principals and how they manage to address disruptive behaviour (Sarantakos, 2013). Indeed, he wanted to explore this topic based on the interpretation of their experiences (Blaxter, Hughes \& Tight, 2014).

The qualitative approach allowed the researcher to use focus-group interviews with educators, parents and students, and one-to-one interviews with the principals and the superintendents. Semi-structured interviews were used as they are dynamic and interactive (Davies \& Hughes, 2014) and therefore could be used to gather information from the selected key informants about leadership and student discipline management. Non-participant observation was also done by the researcher to collect information about the setting in which the principal leads and how he/she did so to deal with the topic under study. 


\section{Ml Macrothink}

International Research in Education

ISSN 2327-5499

2018, Vol. 6, No. 1

The population of the study consisted all the students in the eleven state secondary schools in the educational zone 2 of Mauritius.

The sample consisted of six state secondary school principals, two superintendents, twenty-four educators, twenty-four parents, twenty-four secondary school students and twenty-four parents. The sample for the study consisted of 80 participants. The convenient purposive sampling was used to select the participants. The educators were selected from those who had at least five years of teaching experience in a state secondary school; the selected principals had at least five years of school headship; the students were selected from those who formed part of the Student Council; the parents were selected among those who were members of the school governing body (SGB) and the selected superintendents had at least ten years in the post.

Data analysis was done through an inductive approach of content analysis. The six steps of the data analysis by Lodico, Spaulding and Voegle (2010) were used: the data were prepared and organised; they were reviewed and explored; they were coded into categories; thick descriptions of participants, places, and activities were constructed; themes were built; and finally, the data were interpreted.

\section{Ethical Considerations}

Authorisation for access to the research sites for data collection was sought and obtained from the Ministry of Education and Human Resources, Tertiary Education and Scientific Research. Prior written and verbal consent was obtained from the adult participants as well as written assent from the students and they were explained the aims of the study, that their participation and withdrawal from it at any time during the process interview was voluntary, and that there were strict confidentiality and anonymity of about their identity and participation in the study. A tape-recorder was used for the purpose. The researcher acceded to one principal's refusal to use it but proposal to use pen and paper. Debriefing was made before the data collection to avoid participant deception, and member checks were used after it to confirm the gathered information and share the findings with them. These considerations ensured the trustworthiness of the study.

\section{Findings}

The purpose of the study was to analyse the leadership approaches adopted by the state secondary school principals in managing students' disruptive behaviour in Mauritius. Five themes were identified from the gathered information from the principals themselves, the educators, the students, the superintendents and the parents of the selected schools on the topic. These themes were visionary leadership, learner leadership, inclusive leadership, ethical leadership and distributed leadership.

\subsection{Visionary Leadership}

As visionary leaders, principals communicate their vision for student behaviour regularly. The field notes of the researcher-observer in School A reported that the principal walks through the classes during the Form Master's periods where he talks to the learners about the importance of 
wearing the proper uniform, of regularity and punctuality, of respecting values and social norms of the society and the school and of education in the life of any person. In the same vein, Principal C added: "I should do awareness about the importance of good learner behaviour by talking to them in the morning assembly." Moreover, the School Management Manual stipulates that principals should "remind learners and staff of the vision, mission and objectives of the school and the values taught such as discipline, hardwork, spirit of service and the sense of school connectedness and of responsibility" (Ministry of Education, Culture and Human Resources, 2009). It is evident that the principal as a visionary leader emphasises prevention over punishment. Indeed, according to Wyatt (2015) and Teckchandani and Schultz (2014), the principal must talk to learners to inspire them to be good learners and to learn socially acceptable behaviour.

However, late coming of learners and bunking classes hamper the effectiveness of the principal as the visionary leader who communicates about models of positive learner behaviour in the morning assembly. Principal D lamented in this sense: "Some learners do not come to the assemblies, but to the school canteen." Some learners are unaware of the principal's vision about learner discipline. So, they may still misbehave. In addition, learners are not really interested in adults talking to them about discipline. This is illustrated by the statement of Educator 4 of School C: "Sometimes it works effectively; sometimes not. Learners get everything on a plate, easily from parents. So, they do not realise the importance of education and being a model in terms of behaviour at school." Also, when learners do not take ownership of the school rules and regulations due to the absence of pupil voice and choice and learner leadership, they often challenge the authority of the principal (Maphosa \& Mammen, 2011). Learner 2 of School A commented with much pride: "The school rules are there in the school handbook and the student journal since the first day at school, but we do not care about them as the principal never gives any consequences to us when we break the rules." School rules and regulations are prescribed and imposed on learners, so learners are not compliant to them.

\subsection{Learner Leadership}

The principals interviewed revealed that they give opportunities to learners to be involved in the student council, class prefectship and the organisation of important school events. Principal C explained: "We have the student council, class prefect body and bus prefect body. Learners who are members of these bodies are assigned the responsibility to report any manifestation of a lack of discipline. The bus prefects ensure good learner behaviour in the school bus; the School Management Team (SMT) is informed of any serious misbehaviour. Then actions are taken to correct the misbehaviour. So, learners are collaborating with the SMT." Such a collaboration and student participation contribute toward trust-building, shared relationships, and the creation of a saner and safer school learning environment (Pederson et al., 2011; Barr \& Saltmarsh, 2014; Schleicher, 2015).

However, the findings revealed also that learners are only involved in the consultative meetings; they are not given the opportunity to participate actively in decision-making. Indeed, the School Management Manual states that "the principal should meet the school prefects and the student council twice an academic term to inform them of the specific 
problems in the school and of the actions being taken by the SMT and by the Ministry. The principal should communicate the time frame for the implementation of the solutions to the problems" (Ministry of Education, Culture and Human Resources, 2009). It is evident that the Ministry allows a limited or contrived role to learners in decision-making in terms of learner discipline. They have no voice and choice (Mitra, 2006). When learners are not involved in the drafting of disciplinary measures and they are forced to abide by them, they manifest a lack of discipline (Pagliaro, 2011). In fact, the contrived collegiality practice by principals is not compatible with choice-making as a technique of positive discipline, and it gives the learners the impression that their commitment to the school vision is tokenistic (Jared \& Thinguri, 2017).

Besides, learners who dedicate themselves to contributing to positive discipline by participating in school structures are often victims of poor discipline against them. Learner A, who is a class prefect, shared her experience: "One learner was using her mobile phone to talk to a stranger in the classroom in the absence of the educator. When the latter was back to the class, I reported the girl's lack of discipline. But, after the school bell rang in the afternoon, the mischievous girl, together with mother, physically assaulted me". So, these learners are not protected and empowered by the school principal. It is evident inclusive leadership, as a strategy to include learners to maintain learner discipline, is not effective.

\subsection{Inclusive Leadership}

The study revealed that there is a disciplinary committee in each state secondary school. This follows the recommendations of the Student Behaviour Policy document of the Ministry of Education which stipulates: "It is common practice in schools to set up their disciplinary committee to support the school administration in maintaining discipline....both staffs and students are represented in the committee." (Ministry of Education and Human Resources, Tertiary Education and Scientific Research, 2015). Principals and educators elaborated on the advantages of having such a committee at the school: educators may refer cases of disruptive behaviour to it, which does counselling and uses logical consequences like detention and special reports. Educator 3 of School A pointed out the importance of such a committee: "The committee discusses about the reasons for a student to show disruptive behaviour and makes decisions about the disciplinary measures that may be taken to modify his/her behaviour. As a group, the educators may be more effective in discipline management. Once a student faces the disciplinary committee, he/she will not repeat the same disruptive behaviour."

However, the statement by the educator is contradicted by another educator in School $\mathrm{C}$ who argued that disciplinary measures that are taken are never taken collectively by the committee. He spoke out his concern as such: "The decisions are taken by the principal and some senior staff." Because of this so-called team decision that is formed easily, but with no concrete and effective measures to counteract the problem of students' disruptive behaviour (Van der Mescht \& Tyala, 2008), educators are discouraged to be part of the disciplinary committee and to contribute to the promotion of positive behaviour. Educator 2 of School D clearly shared his frustration: "I think a disciplinary committee is a white elephant committee. Educators are just requested to be part of it by the principal, but they can do nothing to 
successfully discipline students. In such a situation, Educators like me will never be keen to do one of its members."

From the study, it became obvious that even when the disciplinary committee has a limited authority to maintain discipline, its power to execute the disciplinary measures is constrained by the United Nations Convention on the Rights of the Child 1989, the African Charter on the Rights and Welfare of the child 1990 and passed the Child Protection Act 1994 and the Ombudsperson for Children Act 2003 protect the students' constitutional rights. There is also political intervention which parents of misbehaved students seek from the affluent Member of Parliament of their constituency to disempower the decision taken by the committee or the school principal. To illustrate this constraint, the principal of School D lamented: "Last year, I suspended a learner who brought synthetic drug to school. His parent did not agree to the disciplinary measure, so she went to the Citizens Advice Bureau of her constituency where she met the elected MP to talk about the situation. The MP intervened at the Ministry of Education and I received a call from the same ministry requesting to stop the detention against the student immediately." So, it is clear that though the principal adopts the inclusive leadership, yet he/she is not always successful in dealing with disruptive behaviour. This is confirmed by Pascal (2015) who asserts that school principals and educators fail to maintain positive student discipline because of political intervention.

\subsection{Ethical Leadership}

The primary aim of the school is to ensure that the student behaviour is in line with the norms of the school as an institution and those of the society at large (Yidirim \& Bastug, 2010). According to Lynch (2015), the eight principles that a school principal must follow to be successful leader of student discipline are personal courage; public interest ahead of self; self -control, self-discipline and integrity; student-centeredness, recognising students' talents; requiring high ethics in terms of behaviour expectations from the students; sensitivity and understanding of the students' needs, problems and interests; and inclusiveness.

This study revealed that the school principal transmits moral, social, cultural and ethical values to the students in the morning assemblies. He/she transmits the school and human values such as self-respect, respect for others, sharing, social justice and unity in diversity. All the interviewed principals recognised the importance of being ethical. This is arrogantly stated by the principal of School B: "I talk to the students about discipline until they buy-in the disciplinary measures or the importance of discipline." Learner 2 of School C concurred with the principals by pointing out: "The principal sensitises the students about the importance of punctuality, respecting the educator, the values of education, our responsibility towards our hard working parents, respecting other's property, etc when she gets in the classroom during the form master's period." By using the ethical leadership, the principal prefers adopting the prevention policy to student discipline rather than using intervention when there is a manifestation of a lack of discipline. Indeed, he/she must adopt proactive rather than reactive disciplinary measures. Such a leadership provides a holistic support to the students since they know clearly what are the school's behaviour expectations from them (Rhimm-Kaufman \& Chiu, 2007). 


\subsection{Distributed Leadership}

The findings of this study revealed that when the principals share their authority and power to the educators and the school superintendents, they fail in maintaining effective student discipline. They do not get the full collaboration of these two essential agents of change in the school context. As a matter of this fact, principals lacks control over their professional functions, including the leading of the student behaviour.

Educator 2 of School D did not hesitate to voice out his opinions about his refusal to help the principal in discipline management: "When my principal empowers me, it means she gives me the opportunity and authority to take disciplinary actions in her absence. But, I prefer to develop a laissez-faire attitude to disruptive behaviour in order to avoid any problems with affluent parents who may be political agents, with the Ministry which has a long protocol for cases of indiscipline, or worst with the police if parents find the constitutional rights have not been observed by me in applying negative consequences. Today, people talk about the sixteen children rights, the Convention of Children's Rights, Children Protection Act, and the Education Act." One of the principals lamented with much frustration about the educators who do not collaborate: "Though, I recommend their involvement in disciplining students in the staff meetings, yet they leave this task only my shoulder. But, I cannot be physically present in all classes for student discipline management." It is obvious that the educators have shifted part of their responsibility onto the principal alone.

The school superintendents are also reluctant to help the principal in his/her leadership. They are overloaded with many paper work. The superintendent of School C complained in this sense: "When the principal refers a case of indiscipline to me, I can hardly find time to look into the problem, so much administrative matters to settle the whole day. There are one thousand students in this school, if most of them misbehave, do you think I will be able to the follow-up for all of them? I really can't do the follow-up. I get stuck in my office here" This finding is consistent with Ntombela (2014) who also found that the superintendent has many administrative tasks to do that they cannot look into other school matters. The principal of the state secondary school therefore remains helpless and disempowered to be solely responsible for student indiscipline. Yet, it is clearly mentioned in the Student Management Manual for Principals and the Pay Research Bureau that the superintendent and the educators respectively are also responsible for maintaining discipline at schools (Ministry of Education, culture and Human Resources, 2009; Pay Research Bureau, 2008).

It is obvious from the above findings that state secondary school principals in Mauritius should be ambidextrous leaders who are able to manage their time and resources by navigating between these different types of leadership in order to lead student behaviour effectively on a daily routine school day. They need to have the collaboration of all the stakeholders who should take their responsibilities and assume their tasks and duties in relation to learner discipline management. Power-sharing and trust would be the key elements in the leadership practice. The superintendent should dedicate some of his/her time to learner discipline, the educators should participate in the morning assemblies and monitor, on a roaster basis, for instance, the student behaviour in the hallways, on the playgrounds and the 
canteen, and the students who are part of the SGB and the Student Councils must actively monitor the student behaviour in the school bus and during extracurricular activities (the school principal must not only give them the authority to do so but must also teach them to respect the empowered students of these bodies. The school principal must reorganise the daily tasks and responsibilities of these stakeholders so that there is a system or structure of student behaviour management in the school to ensure the school discipline plan is successfully implemented daily.

The school principal must develop a learner discipline plan, in close collaboration with all the stakeholders, in which the school vision for student discipline, the behaviour expectations, the discipline policies, procedures and processes, the evidenced-lbased disciplinary interventions, the logical consequences, the role of the educators, school superintendent, the parents and the students of the SGB and the Student Council are well explained, communicated and implemented.

\section{Discussion}

The findings of this current study showed that the state secondary school principals in Mauritius adopt a combination of leadership approaches. This confirmed Yildirim and Bastug (2010) who argue that leadership is only successful when it has multidimensional features. Such a type of leadership helps the principal to prepare the norms or behaviour framework that directs the behaviour of students in the school. One particular leadership approach is necessary but not sufficient for them to effectively lead student discipline. It was obvious that each type of leadership has its advantages as well as disadvantages that eventually hamper its effectiveness.

The state secondary school principals should therefore adopt a situational leadership style whereby the leadership approach used must be aligned with the state and nature of the student discipline in the particular school. It is their sole responsibility to make a situational analysis of the problem and, based on the data collected, design the school discipline plan. They cannot neglect the visionary aspect of student discipline management nor strive to do so on their own by excluding the educators, school superintendent, the students or the parents; they have to empower them to work as a team of student discipline leaders; and they must be ethical in their leadership.

Though Nooruddin and Baig (2014) found that the student behaviour is influenced by the principal's leadership in terms of policies, procedures and practices concerning the management of the behaviour of student. Yet, this study showed that the principal's leadership in managing student behaviour is influenced by the attitudes of the educators, the superintendents and students in the school. He/she may be prepared to adopt a particular leadership, but the extent of his/her effectiveness in doing so depends largely on these stakeholders. In this study it became obvious that the principal alone cannot tackle the problem of student indiscipline as students' disruptive behaviour is a personal or individual problem that needs the involvement of the most concerned people to bring the solutions to it. The students, the educators and the students must be motivated to give a helping hand in the process of student discipline management. In other words, student discipline management 
must be a product of collective efforts and will of all these people so that there is a safer school environment. It appears that in state secondary schools of Mauritius, the authority and the leadership of the principals are constrained by both internal and external factors to the school: the centralisation of educational policies and procedures, the contrived collegiality of the educators in the school discipline committee and that of students in the student council, the political interference of elected Members of Parliament in the day-to-day management of student behaviour, the long discipline protocol drafted by the Ministry of Education to which the principal must abide to when dealing with cases of indiscipline, the educator's don't-care-attitudes to the manifestation of a lack of discipline at school, and the legal framework concerning the constitutional rights of the child.

However, while analysing the information gathered from the participants of this study, it has become obvious also that principals think more in terms of sanctions and other types of punitive or reactive disciplinary strategies. Such strategies refrained the collaboration of the educators. Proactive measures have not been sufficiently mentioned neither by the educators nor by the students. This may constitute another barrier to the effective leadership of student behaviour management in state secondary schools.

\section{Recommendations}

From the above discussion based on the findings of this study, it is recommended that the Ministry of Education give a greater authority to manage student behaviour at the school level. Since discipline is complex and contextual to the specific school, principals may more effectively manage discipline if they are authorised to take decisions concerning cases of indiscipline at the school administration level. This is likely to eliminate the long time-consuming process of respecting the protocol imposed by the Ministry of Education. This will also give more confidence to the principal and make him/her more trustworthy as the authority of the school.

The principal should also adopt mostly instructional leadership and ethical leadership so that they may lead by examples and therefore model positive behaviour in his/her students. $\mathrm{He} /$ she must be inspirational to them by adopting the values-based leadership as well.

Moreover, the principal must adopt the school-wide positive behaviour system in which everyone in the school is part and parcel of the comprehensive disciplinary framework which the school community must set up for implementation. To be successful here, the principal must use the visionary leadership which allows him/her to follow him/her in his/her endeavor to create an effective school based on positive student discipline. Indeed, effective leadership brings about positive student behaviour which in turn brings about students' outstanding academic success.

\section{Conclusions}

This study has examined the possible leadership that the principal must adopt to manage student behaviour more effectively. It has provided insights into the barriers to the capability of the school head in creating a conducive teaching and learning environment, through his/her leadership. From these perspectives, it is now obvious that the principal should use a mix of 


\section{Macrothink}

International Research in Education

ISSN 2327-5499

2018, Vol. 6, No. 1

different leadership approaches in order to get the best features of them to be successful in student behaviour management.

\section{References}

Asiyai, R. I. (2012). Indiscipline in Nigerian secondary schools: Types, causes, and possible solutions. African Journal of Education and Technology, 2(1), 39-47.

Baltaci, A., \& Balci, A. (2017). Complexity Leadership: A theoretical perspective. International Journal of Educational Leadership and Management, 5(1), 30-59. http://dx.doi.org/10.17583/ijlem.2017.2435.

Barr, J. \& Saltmarsh, S. (2014). "It all comes down to the leadership": The role of the school principal in fostering parent-school engagement. Educational Management Administration and Leadership, 1-15.

Bawany, S. (2015). Discovering your authentic leadership: How can you become and remain an authentic leader? Leadership Excellence Essentials, 32(3), 30.

Bear. G. G. (2010). Discipline: Effective school practices. Helping Children at Home and School III. National Association of School Psychologists, 1-4.

Beebeejaun-Muslum, Z. N. (2014). Delinquant and antisocial behaviour in Mauritian secondary schools. Research Journal of Social Science and Management, 3(12), 124-135.

Bell, C. (2015). The oath of leadership: Great leaders expect the best of all they influence. Leadership Excellence Essentials, 32(1), 18.

Belle, L. J. (2015). Educational Leadership and management. Reduit: Open University of Mauritius.

Belle, L. J. (2017). A critical review of the current education system of Mauritius and the learner discipline problem in Mauritian state secondary schools. Journal of Education and Social Sciences, 8(1), 47-55.

Blaxter, L., Hughes, C., \& Tight, M. (2014). How to research. UK: Open University Press.

Carr, J. \& Chearra, S. M. (2004). Managing challenging behaviour: Guidelines for teachers. Dublin: Irish National Teachers' Organisation.

Chakraborty, R., Tarafdar, M., \& Ahmad, S. R. (2017). A review on no detention policy and its impacts on different school boards in West Bengal. International Journal of Advanced Education and Research, 2(3), 159-161.

Curran, F. C. (2017). The law, policy and portrayal of zero-tolerance school discipline: Examining prevalence and characteristics across levels of governance and school districts. Educational Policy. http://doi.org/10.1177/0895904817691840.

Darch, C. B. \& Kameenui, E. J. (2003). Instructional classroom managiement: A proactive approach to behaviour management. White Plains, NY: Longman. 


\section{$\triangle$ Macrothink}

International Research in Education

ISSN 2327-5499

2018, Vol. 6, No. 1

Das, R. (2017). Impact of school-wide positive behaviour supports on behaviour. International Journal of Education and Psychological Research, 6(2), 61-63.

Davies, M. \& Hughes, N. (2014). Doing a successful research project using qualitative or quantitative methods. London: Palgrave MacMillan.

Dhammika, K. S. (2016). Visionary Leadership and organizational commitment: The mediating effect of leader member exchange (LMX). Wayamba Journal of Management, 4(1), 1-9. http://doi.org/10.4038/wjm.v4i1.7452

Dos, I., \& Savas, A. A. (2015). Elementary school administrators and their roles in the context of effective schools. Retrieved from http://www.journals.sagepub.com/doi/pdf/10.1177/2158244012158244014567400

Eden, M. (2017). School discipline reforms and disorder: Evidence from New York City public schools, 2012-16. NY: Manhattan Institute. [Online] Available: https:/www.manhattan-institute.org/html/school-discipline-reform-and-disorder-evidence-ny c-schools-10103.html (November 5, 2017).

Edinyang, S. D. (2017). Maintaining discipline in a social studies classroom. International Journal of Sociology and Anthropology Research, 3(2), 54-60.

Farah, A. I. (2013). School management: Characteristics of effective principal. Global Journal of Human-Social Science, 13(13), 13-16.

Fields, M. V. \& Fields, D. (2006). Constructive Guidance and discipline: Preschool and primary education. Ohio, USA: Pearson Prentice Hall.

Gambo, M. A., \& Muktar, A. L. (2017). Forms, causes and effects of indiscipline on teaching and learning in secondary schools in Maiduguri Metropolitan Council, Borno State. International Journal of Innovative Research and Advanced Studies, 4(1), 151-156.

Glasser, W. 2001. Counselling with choice theory. The reality therapy, Harper Collins.

Hallinger, P., Walker, A., Nguyen, D., Truong, T., \& Nguyen, T. (2017). Perspectives on principal instructional leadership in Vietnam: A preliminary model. Journal of Educational Administration, 56(2), 22-239. http://doi.org/10.1108/JEA-11-2015-0106

Hulac, D., Terell, J., Vining, O. \& Verstein, J. (2011). Behavioural interventions in schools: A Responsive-to-Interventions guidebook. New York: Routledge.

Jared, O. O., Thinguri, R. W. (2017). A critical analysis of effectiveness of student council on learner discipline management in secondary schools in Kenya. International Journal of Applied Research, 3(1), 90-97.

Kirkpatrick, S. A. (2004). Visionary leadership theory: encyclopedia of leadership. NY: SAGE publication.

Lane, K. L., Cook, B. G. \& Tankersley, M. (2013). Research-based strategies for improving outcomes in behaviour. Upper Saddle River, NJ: Pearson Education Inc. 


\section{Ml Macrothink}

International Research in Education

ISSN 2327-5499

2018, Vol. 6, No. 1

Lane, K. L., Menzies, H. M., Bruhn, A. L. \& Crnobori, M. (2011). Mamaging challenging behaviours in schools: Research-based strategies that work. New York: Guilford Press.

Larmer, R. (2001). Humility and vision in the life of effective leader. San Francisco, CA. Retrieved from www.Emerald.com

Lazaridou, A. (2009). The kinds of knowledge principals use: Implications for training. International Journal of Education Policy and Leadership, 4(10), 1-15. http://doi.org/10.22230/ijepl.2009v4n10a187.

Lieber, C. M., \& Tissiere, M. (2015). Recalibrating climate, culture and discipline: To be effective, you may have to change gears. Principal Leadership. Retrieved from http://engagingschools.org/wp-content/uploads/2015/11/Recalibrating-Climate-Culture-andDiscipline-Oct-2015.pdf.

Lodico, M. G., Spaulding, D. T. \& Voegtle, K. H. (2010). Methods in educational research: From theory to practice. San Francisco, CA: Jossey-Bass.

Lynch, M. (2015). The eight principles of ethical leadership in education. [Online] Available: http://www.theadvocate.org

Mahatmaharti, A. K., Triyono, W. A., \& Hanurawan, F. (2017). Construct validity in research instruments: The analysis of self-discipline factors. IOSR Journal of Humanities and Social Science, 22(6), 33-40. http://doi.org:10.9790/0837-2206063340.

Manaseh, M. A. (2016). Instructional leadership: The role of heads of schools in managing the instructional programme. International Journal of Educational Leadership and Management, 4(1), 30-47. http://doi.org: 10.17583/ijelm.2016.

Maphosa, C. \& Mammen, K. J. (2011). Disciplinary measures used in South African schools: How do learners view their effectiveness? Journal of Social Science, 29(2), 143-149.

Maulod, S. A., Piaw, Y. C., Alias, S., \& Mei Wei, L. (2017). Relationship between principals' emotional intelligence and instructional leadership practices in Malaysian secondary schools. International Journal of Advanced and Applied Sciences, 4(3), 122-129.

McDargh, E. (2015). Great leadership: Six essential leadership skills for today's leader. Leadership Excellence Essentials, 31(10), 5.

Meador, D. (2017). The role of the principal in schools. Retrieved from https://www.thoughtco.com/guide-to-school-discipline-for-principals

Mendels, P. (2012). The Effective principal. Leadership, 33(1), 54-58.

Ministry of Education and Human Resources, Tertiary Education and Scientific Resources. (2015). The Student Behaviour Policy. Phoenix: IVTB House.

Ministry of Education, Culture and Human Resources. (2009). The School Management Manual: Policies, procedures, and guidelines on school management issues. IVTB House, Phoenix: School Management Division. 


\section{Macrothink}

International Research in Education

ISSN 2327-5499

2018, Vol. 6, No. 1

Mitra, D. (2006). Increasing student voice and moving towards youth leadership. The Prevention Researcher, 13(1), 7-10.

Moges, B. (2017). Classroom management problems and coping strategies of students' misbehavior in government secondary schools of Arsi zone. International Journal of Education and Psychological Research, 6(1).

Mukuria, G. (2002). Disciplining challenges: How do principals address the dilemma? Urban Education, 37(3), 432-452.

Naganandini, R. (2017). Self-esteem among adolescents. International Journal of Advanced Education and Research, 2(4), 198-199.

Naicker, S. R. \& Mestry, R. (2013). Teachers' reflections on distributive leadership in public primary schools in Soweto. South African Journal of Education, 33(2), 1-15.

Ncontsa, V. N., \& Shumba, A. (2013). The nature, causes and effects of school violence in South African high schools. South African Journal of Education, 33(3), 1-15.

Newcomer, L., \& Lewis, T. (2016). Building connections between individual behaviour support plans and school-wide systems of positive behaviour support. Retrieved from www.pbis.org/newsletters/volume 4.

Newcomer, L., \& Lewis, T. (2016). Building connections between support plans and school-wide systems of positive behaviour support. Retrieved from https://pbis.org/newsletter/vol4

Nooruddin, S., \& Baig, S. (2014). Students behaviour management: School leaders' role in the eyes of teachers and students. International Journal of Whole Schooling, 10(2), 1-20.

Ntombela, L. S. (2014). Secondary school principals' implementation of instructional leadership in the Amajuba district of Kwazula-Natal. Unpublished Masters' dissertation. Pretoria: University of South Africa.

Nwachukwu, C., Chladkova, H., Zufan, P., \& Otlatunji, F. (2017). Visionary leadership and its relationship to corporate social responsibility. Imperial Journal of Interdisciplinary Research, 3(4), 1302-1311.

O'Brien, D. A. (2015). Leadership engagement as job one: Things you can do now. Leadership Excellence Essentials, 32(3), 22.

Olley, R. I., Cohn, A. \& Cowan, K. C. (2010). Promoting safe schools and academic success: Moving your school from punitive discipline to effective discipline. National Association of School Psychologists, 7-8.

Olowoselu, A., \& Aishatu, S. B. (2017). Challenges to secondary school principals' leadership in northern region of Nigeria. British Journal of Education, 3(3), 1-5.

Osher, D., \& Kandziora, K. (2010). Building conditions for learning and healthy adolescent development: Strategic approaches. In B. Doll, W. Pfohl \& J. Yoon (Eds), Handbook of Youth 
Prevention Science. New York: Routledge.

Pagliaro, M. M. (2011). Educator or bully? Managing the $21^{\text {st }}$ Century classroom. Maryland: Rowman and Littlefield Education.

Pascal, L. M. (2015). Secondary schools: the kids are not alright. Education weekly, 21-17 May.

Pay Research Bureau. (2008). Review of pay and grading structures and conditions of service in the public sector and the private secondary schools. Republic of Mauritius: Government of Mauritius.

Pedersen, J., Yager, S. \& Yager, R. E. (2011). Student Leadership ambassadors: Effects of leadership distribution using a student-centered leadership program. E-Journal of Organisational Learning and Leadership, 9(1), 23-34.

Protheroe, N. (2011). A school-wide, proactive approach to discipline. Principal's Research Review, 6(4), 1-8.

Pushpa, M. (2014). Discipline problems and leadership qualities in management of discipline in a secondary school. International Journal of Education and Psychologïcal Research, 3(4), $58-62$.

Rahman, O. A., Shahrin, N. N., \& Kamaruzaman, Z. (2017). The Relationship between parenting style and self-concept. Journal of Education and Social Sciences, 7(1), 190-194.

Ramharai, V., Curpen, A., Mariaye, H. \& Ramful, A. (2006). Disciplime/Indiscipline and violence in secondary schools in Mauritius. Reduit: Mauritius Institute of Education.

Sarantakos, S. (2013). Social research. London: Palgrave MacMillan.

Schleicher, A. (2015). Schools for 21st-Century Learners: Strong Leaders, Confident Teachers, Innovative Approaches. International Summit on the Teaching Profession, OECD Publishing.

Serame, N. J., Oosthuizen, I. J., Wolhuter, C. C., \& Zulu, C. B. (2013). An investigation into the disciplinary methods used by teachers in a secondary township school in South Africa. Koers - Bulletin for Christian Scholarship, 1-6.

Shatalebi, B., \& Yarmohammadian, M. H. (2011). Value-based leadership paradigm. Procedia Social and Behavioural Sciences, 15, 3703-3707.

Sisman, M. (2011). The pursuit of excellence in education and effective schools. Ankara, Turkey. Pegem.

Smyth, G. (2015). Ambidextrous leadership: The perfect balance that leads to great leadership. Leadership Excellence Essentials, 32(2), 29.

Teckchandani, A., \& Schultz, F. C. (2014). The vision thing: An experiential exercise introducing the key activities performed by leaders. Journal of Leadership Studies, 8(1), 63-69.

Temitayo, O., Nayaya, M. A., \& Lukman, A. A. (2013). Management of disciplinary problems 


\section{Macrothink}

International Research in Education

ISSN 2327-5499

2018, Vol. 6, No. 1

in secondary schools: Jalingo Metropolis in focus. Global Journal of Human Social Science, Linguistics and Education, 13(14), 7-19.

Themane, M., \& Osher, D. (2014). Schools as enabling environments. South African Journal of Education, 34(4), 1-6.

Ugboko, F. E., \& Adediwura, A. A. (2012). A study of principal supervisory strategies and secondary school discipline. Journal of Educational and Social Research, 2(1), 41-49.

Van der Mescht, H. \& Tyala, Z. (2008). School principals' perceptions of team management: A multiple case-study of secondary schools. South African Journal of Education, 28, 221-239.

Vielmetter, G. \& Sell, Y. (2014). Tomorrow's leaders: 6 global megatrends creating far-reaching challenges. Leadership Excellence Essentials, 31(8), 41-42.

Walcott, D. M., Grimm, K. \& Konstan, E. (2012). Citywide standards of intervention and discipline measures. NYC: Department of Education.

Witz, G. (2014). Are you decisive? Decisiveness drives success for companies. Leadership Excellence Essentials, 31(10), 11-12.

Wyatt, D. B. (2015). Successful leadership: Three keys. Leadership Excellence Essentials, 32(4), 58.

Yildirim, A., \& Bastug, I. (2010). Teachers' view about ethical leadership behaviours of primary school directors. Procedia Social and Behavioural Sciences, 2, 4109-4114.

\section{Copyright Disclaimer}

Copyright reserved by the authors.

This article is an open-access article distributed under the terms and conditions of the Creative Commons Attribution license (http://creativecommons.org/licenses/by/3.0/). 